\title{
Soil water content and wood ash fertilization on the cultivation of gladiolus
}

\author{
Marcel T. J. Pereira ${ }^{1}$, Tonny J. A. da Silva ${ }^{1} \&$ Edna M. Bonfim-Silva ${ }^{1}$ \\ ${ }^{1}$ Universidade Federal de Mato Grosso/Instituto de Ciências Agrárias e Tecnológicas. Rondonópolis, MT. E-mail: marcel-job@hotmail.com; \\ tonnyjasilva@hotmail.com; embonfim@hotmail.com (Corresponding author)
}

\section{Key words:}

Gladiolus $x$ grandiflorus L. irrigation management ornamental plants solid waste in agriculture

\begin{abstract}
A B S T R A C T
Irrigation management, associated with the management of fertilization through the use of waste from plant material burning, has proven to be a sustainable strategy to increase the production of ornamental plants in greenhouses. The objective of this study was to evaluate the development of gladiolus subjected to soil water contents and wood ash fertilization in a Cerrado Oxisol. The experiment was conducted under controlled conditions from April to September 2014, in a randomized block design, arranged in a $5 \times 5$ factorial, with four replicates. The treatments consisted of five water contents $(7,14,21,28$, and 35\%) and five doses of wood ash $\left(0,8,16,24\right.$ and $\left.32 \mathrm{~g} \mathrm{dm}^{-3}\right)$. Irrigation management was carried out using the portable probe Diviner $2000^{\circ}$. The evaluated variables were: plant height, number of leaves, shoot and root dry matter and diameter and mass of corms. The best results for diameter and mass of corms and number of leaves were obtained with combinations of soil water contents higher than $24 \%$ and fertilization with wood ash doses higher than $11 \mathrm{~g} \mathrm{dm}^{-3}$.
\end{abstract}

\section{Palavras-chave:}

Gladiolus $x$ grandiflorus L. manejo de irrigação plantas ornamentais resíduo sólido na agricultura

\section{Umidade do solo e adubação com cinza vegetal no cultivo do gladíolo}

\section{R E S U M O}

O manejo da irrigação, associado ao manejo de adubação por meio da utilização de resíduos provenientes da queima de material vegetal, tem demonstrado uma estratégia sustentável para o aumento de produção de plantas ornamentais em casa de vegetação. Objetivou-se avaliar o desenvolvimento do Gladíolo da variedade 'White Friendship' submetido à umidade do solo e adubação com cinza vegetal em Latossolo Vermelho do Cerrado. O experimento foi realizado em ambiente protegido, no período de abril a setembro de 2014, em delineamento experimental em blocos casualizados em esquema fatorial 5 x 5, com quatro repetições. Os tratamentos se constituíram de cinco umidades do solo $\left(7,14,21,28\right.$ e 35\%) e cinco doses de cinza vegetal $\left(0,8,16,24\right.$ e $\left.32 \mathrm{~g} \mathrm{dm}^{-3}\right)$. A umidade do solo foi medida com a utilização da sonda portátil Diviner $2000^{\circledR}$. Avaliaramse, no Gladíolo, a altura de plantas, o número de folhas, massa seca da parte aérea e da raiz e o diâmetro e massa dos cormos. Umidade do solo superior a $24 \%$ e adubação com cinza vegetal superior a $11 \mathrm{~g} \mathrm{dm}^{-3}$ proporcionam maior diâmetro, massa de cormos e número de folhas do Gladíolo. 


\section{INTRODUCTION}

Soil moisture is considered of fundamental importance in the yield of crops, especially for those that respond to higher water contents with greater yields. Thus, irrigation becomes a factor that guarantees both the stability of supply of agricultural products and the increase in yield and quality of crops.

Some methods have been used to quantify soil moisture: a) direct - gravimetric, considered as the standard method and b) indirect - neutron probe, electrical resistance, time-domain reflectometry (TDR) and frequency-domain reflectometry (FDR) (Souza \& Matsura, 2002).

The probe Diviner $2000^{\circ}$, a capacitance sensor (FDR), has been used to help the monitoring of soil water and irrigation management and, as its main advantages, provides fast and precise readings in subsurface (Silva et al., 2007). Additionally, the possibility of instantaneous moisture determination makes indirect methods more adequate to indicate the beginning and the duration of irrigation (Leão et al., 2007).

Ornamental plants have different responses to soil moisture and require studies on water managements, since deficient irrigations reflect directly in the reduction of yield, while excessive irrigations undermine flower quality (Farias et al., 2009).

In order to meet the nutritional requirement, fertilization management using residues from the burning of plant material, associated with irrigation management, has proven to be a sustainable strategy for the increase in the production of ornamental plants under greenhouse conditions.

This study aimed to evaluate the vegetative development and the production of corms of gladiolus subjected to different soil water contents and wood ash doses in a Cerrado Oxisol.

\section{Material AND Methods}

The experiment was carried out in a greenhouse, from April to September 2014, at the Federal University of Mato Grosso, Campus of Rondonópolis-MT, Brazil, in the Institute of Agricultural and Technological Sciences - ICAT, located at the geographic coordinates of $16^{\circ} 27^{\prime} \mathrm{S}, 54^{\circ} 34^{\prime} \mathrm{W}$ and altitude of $284 \mathrm{~m}$.

The statistical design was randomized blocks, arranged in a $5 \times 5$ factorial scheme, totaling 25 treatments, with four replicates. The treatments consisted of five levels of volumetric soil water contents $(7,14,21,28$ and $35 \%)$ and five doses of wood ash $\left(0,8,16,24\right.$ and $\left.32 \mathrm{~g} \mathrm{dm}^{-3}\right)$.

The soil material used in the pots was collected in an area under Cerrado vegetation in the layer of $0-0.20 \mathrm{~m}$ of a soil classified as Oxisol of sandy loam texture (EMBRAPA, 2013). Chemical and granulometric characterization of the soil (Table 1) were performed according to EMBRAPA (1997).

Irrigation management was performed through an indirect method, using the portable probe Diviner $2000^{\circ}$ to monitor water contents in the soil profile, which requires the vertical installation of access tubes (PVC - polyvinyl chloride) in the soil, specifically projected for the use of this probe. The access tubes in the present study were installed horizontally, passing through the pots (Figure 1A).

Five experimental pots were arranged in each access tube; therefore, each block consisted of five lines, each one with five experimental units, totaling 25 treatments per block (Figure 1B). Each pot had a useful volume of $16.5 \mathrm{dm}^{3}$, which was filled with soil.

For the use of the Diviner $2000^{\circ}$ capacitance probe in the irrigation management, the reading points were calibrated at each soil water content. The probe performs readings every $0.10 \mathrm{~m}$. Therefore, it was possible not only the validation of points closer to the center of the pots (green and blue points), but also the exclusion of points closer to the plastic of the pots (red points) (Figure 2).

Daily readings were performed in the morning and the mean of the readings (volumetric soil water content) was calculated in each experimental plot. Based on the actual water content and on the volume of soil, the amount of water necessary to reach the desired water content in the treatment was calculated (Eq. 1).

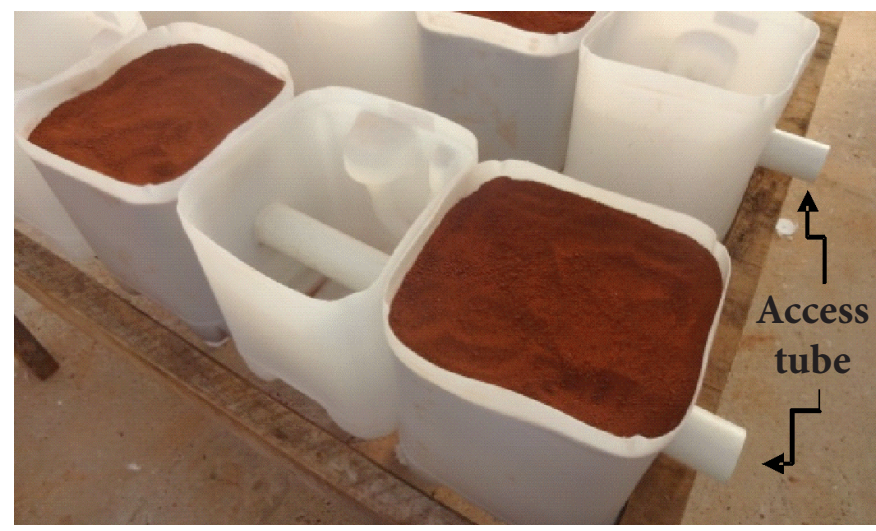

B.

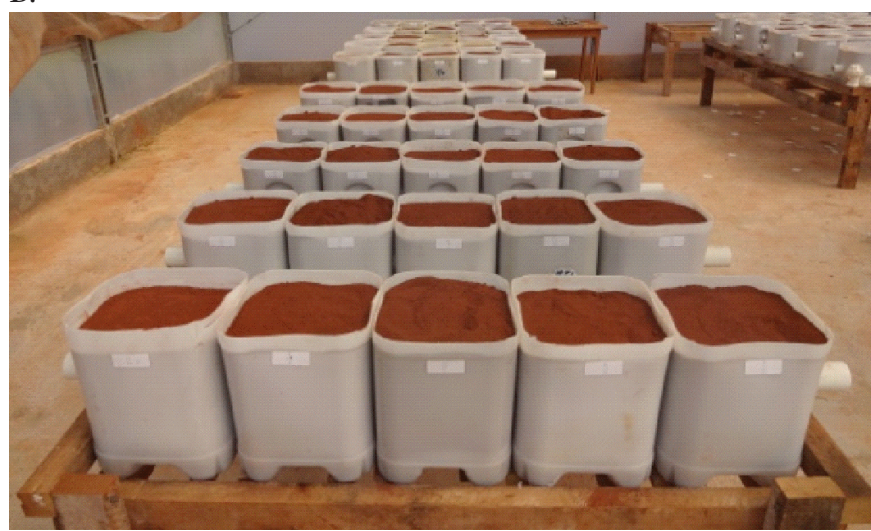

Figure 1. Experimental units with the access tube installed: Detail of the access tube passing through the center of each experimental unit $(A)$; Partial view of the pots with the access tube installed (B)

Table 1. Chemical and granulometric characterization of the sample of Oxisol collected in the layer of 0-0.20 m

\begin{tabular}{|c|c|c|c|c|c|c|c|c|c|c|c|c|c|c|c|}
\hline \multirow{2}{*}{$\begin{array}{c}\mathrm{pH} \\
\left(\mathrm{CaCl}_{2}\right)\end{array}$} & $\mathbf{P}$ & K & $\mathrm{Ca}$ & Mg & H & Al & SB & CEC & \multirow{2}{*}{$\begin{array}{c}V \\
(\%)\end{array}$} & \multirow{3}{*}{$\begin{array}{c}\mathrm{OM} \\
\left(\mathrm{g} \mathrm{dm}^{-3}\right) \\
287\end{array}$} & $\mathrm{H}$ & M & Sand & Silt & Clay \\
\hline & \multicolumn{2}{|c|}{$\left(\mathrm{mg} \mathrm{dm}^{-3}\right)$} & \multicolumn{6}{|c|}{$\left(\mathrm{cmol}_{\mathrm{c}} \mathrm{dm}^{-3}\right)$} & & & \multicolumn{2}{|c|}{$(\%)$} & \multicolumn{3}{|c|}{$\left(g^{k g}{ }^{-1}\right)$} \\
\hline 4.2 & 1.1 & 29 & 0.6 & 0.3 & 5.7 & 0.5 & 0.6 & 7.3 & 13 & & 79 & 35 & 549 & 84 & 367 \\
\hline
\end{tabular}




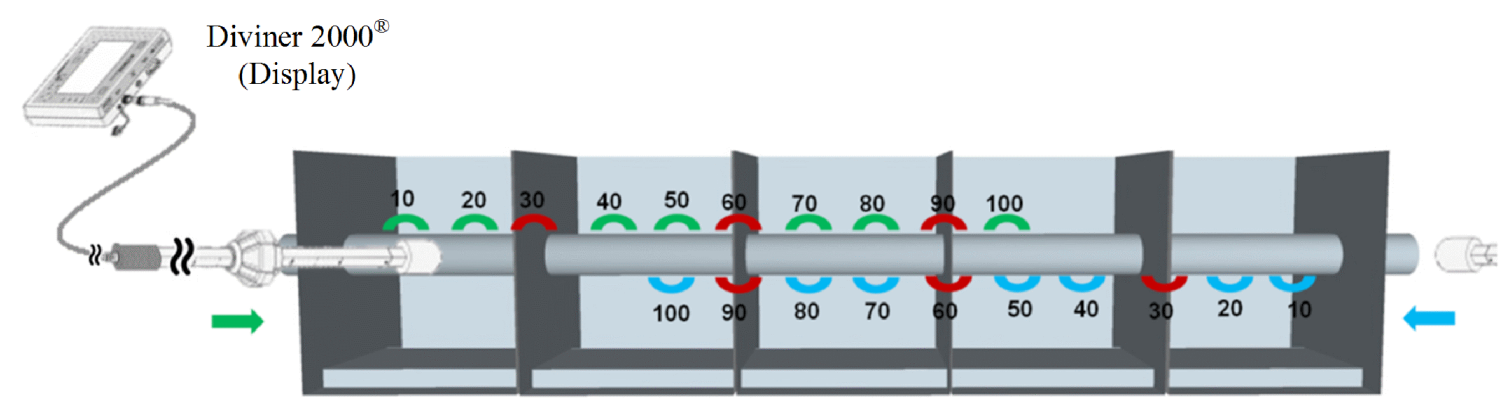

Points used (green and blue); Points excluded (red)

Figure 2. Representation of the lateral view (cut) of the experimental units with the calibration of reading points of volumetric soil water content

$$
\mathrm{V}=(\theta \text { treat. }-\theta \text { actual }) \times 16500
$$

where:

$\mathrm{V} \quad$ - volume of water, in $\mathrm{cm}^{3}$;

$\theta$ treat. - desired water contents in the treatments $(0.07$; $0.140 ; 0.210 ; 0.280$ and 0.320 ), in $\mathrm{cm}^{3} \mathrm{~cm}^{-3}$; and,

$\theta$ actual - soil water content measured by the capacitance probe, in $\mathrm{cm}^{3} \mathrm{~cm}^{-3}$.

The cultivated species was Gladiolus $x$ grandiflorus L., variety 'White Friendship', and four corms were planted in each experimental unit at the depth of $0.10 \mathrm{~m}$.

Nitrogen fertilization was performed in all the experimental plots, using $90 \mathrm{mg} \mathrm{dm}^{-3}$ of urea $\left(\left(\mathrm{NH}_{2}\right)_{2} \mathrm{CO}\right)$. Nitrogen was applied to the soil 14 days after emergence, divided into three applications in the interval of 7 days.

The wood ash used in the experiment consisted of corn stubbles and eucalyptus wood, which was subjected to chemical characterization as a fertilizer (Table 2), as established by Darolt et al. (1993). The wood ash was incubated for 30 days in the soil, for the chemical reaction. Then, soil $\mathrm{pH}$ was characterized in each treatment (Table 3 ).

When plant shoots were cut, 147 days after emergence, roots and corms were separated in each treatment and in all the plants. Shoot fresh matter (leaves + flower stem) was subjected to drying in an oven at $65 \pm 2{ }^{\circ} \mathrm{C}$ until constant mass and then weighed on a semi-analytical scale (precision of $0.001 \mathrm{~g}$ ).

Corm diameter was measured using a digital caliper (precision of $0.01 \mathrm{~mm}$ ) and the mass of corms was determined on a semi-analytical scale. The produced corms were classified according to diameter and mass (Barbosa, 2011). Gladiolus development was analyzed through the response surface methodology using the program "Statistical Analysis System" (SAS Institute, 2002). For the cases in which the interaction between wood ash and soil water content was not significant, first- and second-order regressions were used, through the function GLM (General Linear Model). A significance level of $5 \%$ was used in all the statistical tests.
Table 3. Soil pH after 30 days of incubation with wood ash

\begin{tabular}{cc}
$\begin{array}{c}\text { Wood ash dose } \\
\left(\mathrm{g} \mathrm{dm}^{-3}\right)\end{array}$ & $\begin{array}{c}\text { Soil } \mathrm{pH} \\
\left(\mathrm{CaCl}_{2}\right)\end{array}$ \\
0 & 4.08 \\
8 & 5.68 \\
16 & 6.36 \\
24 & 7.11 \\
32 & 7.80 \\
\hline
\end{tabular}

\section{Results AND Discussion}

In the analysis of variance for the total production of shoot dry matter (SDM) (leaves + stem) of 'White Friendship' gladiolus, there was isolated significance for soil water contents and wood ash doses (Figures $3 \mathrm{~A}$ and $\mathrm{B}$ ).

For the volumetric soil water content, in isolation, shoot dry matter showed a quadratic response, with maximum value $(29.6 \mathrm{~g})$ at the water content of $28.93 \%$ (Figure 3A).

These results show the importance of the water in the physiological processes of the plant and, consequently, in the total dry matter production of gladiolus. This positive response to soil water contents in plant vegetative growth can be explained by the stimulus of the water to a greater assimilation of carbohydrates, since it is a significant component of photosynthesis, besides stimulating the increase in leaf surface.

Farias \& Saad (2011), studying the growth of irrigated chrysanthemum under water tensions in protected environment, observed reduction in leaf area and leaf dry matter at the lowest tensions $(-30 \mathrm{kPa})$, showing the importance of the water for plant growth. Under water stress conditions, the leaves tend to expand less than they would do under adequate water conditions.

It is verified that, under adverse conditions, plants tend to reduce leaf size, as observed at the lowest water contents, decreasing the loss of water through transpiration due to stomatal closure. According to Melo et al. (2010), leaf expansion rate and its photosynthetic contribution are associated with the speed of vegetative growth and a larger leaf area leads to improvements in the production of photoassimilates necessary for a production of quality.

Table 2. Chemical characteristics of the wood ash used as a fertilizer

\begin{tabular}{cccccccccccccc}
\hline $\begin{array}{c}\mathbf{p H} \\
\left(\mathrm{H}_{2} \mathbf{0}\right)\end{array}$ & $\mathbf{N P}$ & $\mathbf{N}$ & $\begin{array}{c}\mathbf{P}_{2} \mathbf{O}_{5} \\
\text { total }\end{array}$ & $\mathrm{K}_{2} \mathbf{O}$ & $\mathbf{Z n}$ & $\mathbf{C u}$ & $\mathbf{M n}$ & $\mathbf{B}$ & $\mathbf{C a}$ & $\mathrm{Mg}$ & $\mathrm{S}$ & $\mathrm{Si}$ & $\mathrm{Fe}$ \\
\hline 11.8 & 25 & 0.25 & 4.85 & 1.66 & 0.013 & 0 & 0.05 & 0.02 & 3.75 & 2.85 & 0.28 & 18.7 & 1.53 \\
\hline
\end{tabular}



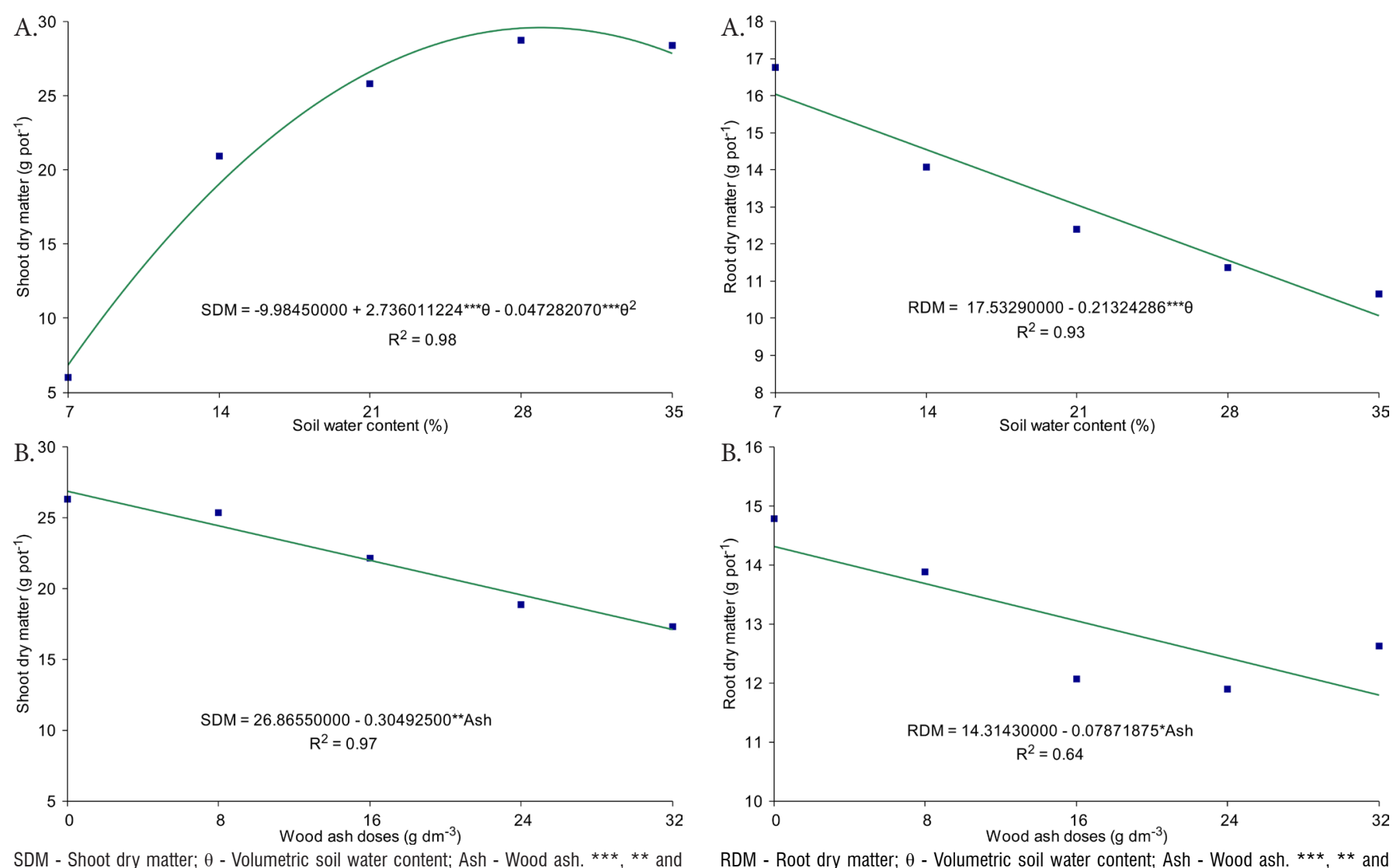

SDM - Shoot dry matter; $\theta$ - Volumetric soil water content; Ash - Wood ash. ${ }^{* * *}$, ** and ${ }^{*}$ Significant at $0.1 ; 1$ and $5 \%$, respectively

Figure 3. Shoot dry matter (leaves + stem) of gladiolus as a function of soil water content (A) and wood ash doses (B) in Oxisol

The lowest production of shoot dry matter, observed at the lowest soil water contents, occurred because the decrease in soil water reduces the water potential in the leaf and its stomatal conductance, promoting stomatal closure (Kron et al., 2009). Such closure may block the flow of $\mathrm{CO}_{2}$ to the leaves and reduce the accumulation of photoassimilates, which can decrease plant yield (Sousa et al., 2010).

Shoot dry matter decreased with the increase in wood ash doses (Figure 3B). According to Malavolta et al. (1997), the application of high doses of $\mathrm{K}$ fertilizer can cause nutritional imbalance in the plants, which may have occurred with the application of wood ash, evidencing the antagonistic effect of $\mathrm{K}$ in relation to the absorption of both $\mathrm{Ca}$ and $\mathrm{Mg}$, since they are all cationic nutrients that strongly compete for the same absorption sites.

Root dry matter production fitted to a linear regression model for soil water contents and wood ash doses (Figure $4 \mathrm{~A}$ and $\mathrm{B}$ ). For the response of root dry matter production to soil water contents, a linear decrease of $42.57 \%$ was observed between the lowest (7\%) and the highest soil water content (32\%) (Figure 4A).

Under conditions of low soil water content, the roots of gladiolus grow deeper, which shows its capacity to adapt to adverse situations. This characteristic of adaptation is important for the plant to tolerate drier periods.

There was a reduction in the root system with the increase in soil water content, possibly due to the decrease in the expenditure of energy by the plant, since the water was more available in the substrate (Figure 4A).

Figure 4 . Root dry matter of gladiolus as a function of soil water contents (A) and wood ash doses (B) in Oxisol

Rena \& Guimarães (2000) claim that, under optimum hydration conditions, root growth tends to be lower than under moderate stress conditions. It is common to observe an essentially superficial root system when all the layers are humid and, when the superficial layers start drying, a proliferation of deeper roots (Costa, 2001), as in the present study.

In addition, the amount of oxygen in the soil is inversely proportional to soil water content, i.e., the higher the amount of water in the soil, the lower the amount of oxygen. According to Taiz \& Zeiger (2010), oxygen is an essential part of cell respiration and ATP (Adenosine triphosphate) is generated in this process, for biochemical reactions in the roots. In the lack of this molecule, there is a reduction in the activity of active absorption of nutrients and water and, therefore, the shoots suffer deficiency of nutrients that are necessary for growth.

A decrease of $17.6 \%$ was observed in root dry matter in the experimental interval, comparing the highest dose $\left(32 \mathrm{~g} \mathrm{dm}^{-3}\right)$ with the control treatment (without wood ash fertilization) (Figure 4B). Additionally, it should be pointed out that root growth depends on genetic characteristics, but is influenced by environmental factors such as temperature, $\mathrm{pH}$, contents of water and nutrients, and by soil compaction. In the present study, soil $\mathrm{pH}$ and water content and nutrients are the factors that influence gladiolus root growth, since the others did not vary.

As to soil $\mathrm{pH}$, wood ash promoted correction of acidity, from 4.0 (soil without wood ash fertilization) to 7.8 in the treatment with $32 \mathrm{~g} \mathrm{dm}^{-3}$ of wood ash (Table 3). Silva et al. (2013), studying wood ash as corrective of acidity and fertility of a Humic Cambisol, obtained a less expressive response in 
the increase in the unit of $\mathrm{pH}$, compared with the results of the present study. These authors used ash with neutralizing power of $7 \%$, while the value was $25 \%$ in the present study.

It is important to consider that gladiolus requires $\mathrm{pH}$ values of 5.5 to 7.0 (Barbosa, 2011), a range in which most nutrients are available to the plant. Thus, it is evident that soil $\mathrm{pH}$ was not responsible for the inhibition of root growth, since the application of wood ash in the range of 8 to $16 \mathrm{~g} \mathrm{dm}^{-3}$ (Table 3) promoted $\mathrm{pH}$ values considered as optimal for the crop. In addition, the exploration of a greater soil volume promoted by the higher root growth observed in the control treatment may have favored the absorption of nutrients in ideal amounts for the vegetative growth, observed at the end of the experiment with the total shoot dry matter.

The analysis of variance for diameter and mass of gladiolus corms was significant for the interaction between wood ash doses and soil water content and fitted to a polynomial regression model (Figures 5A and $\mathrm{B}$ ).

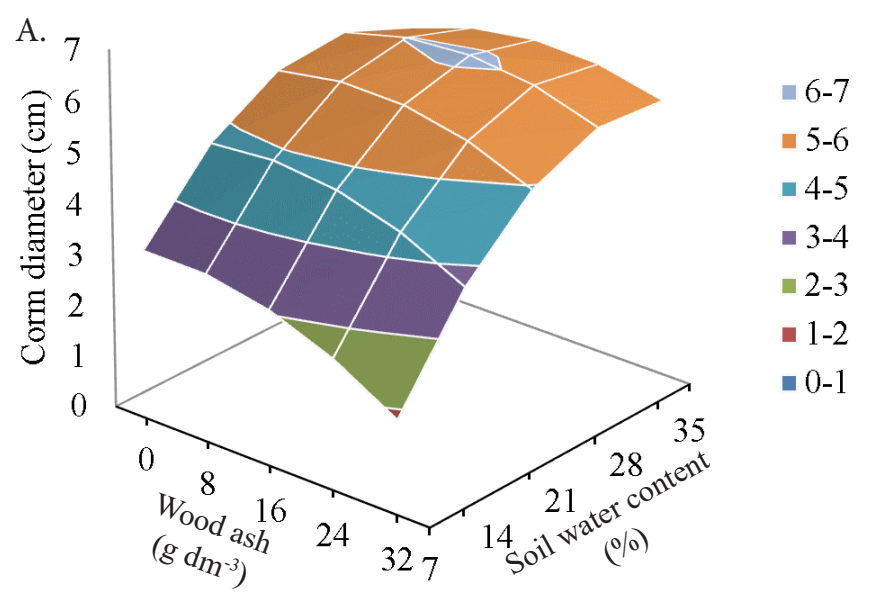

$$
\begin{gathered}
\mathrm{CD}=1.200307+0.350186^{* * *} \theta-0.001849^{* *} \mathrm{Ash}^{2}+ \\
0.001897^{* *} \text { Ash } \theta-0.00676^{* * *} \theta^{2} \\
\mathrm{R}^{2}=0.71
\end{gathered}
$$

B.

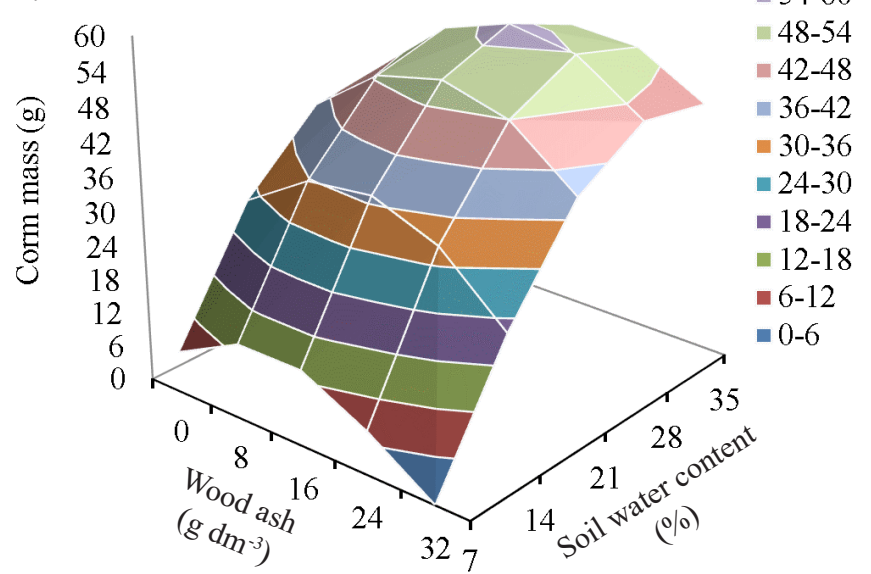

$\mathrm{CM}=-23.229779+0.959673^{*} \mathrm{Ash}-0.045999^{* * *} \mathrm{Ash}^{2+}$

$5.048394^{* * *} \theta-0.096937^{* * * *} \theta^{2}+0.022619^{*} \mathrm{Ash} \theta$

$$
\mathrm{R}^{2}=0.63
$$

CD - Corm diameter; CM - Corm mass; Ash - Wood ash; $\theta$ - Volumetric soil water content $* * *$, $* *$ and ${ }^{*}$ Significant at $0.1 ; 0.01$ and 0.05 , respectively

Figure 5. Diameter (A) and Mass (B) of corms of 'White Friendship' gladiolus at 147 days after emergence as a function of combinations of soil water content and wood ash doses in a Cerrado Oxisol
According to the response surface, the wood ash doses of 14.31 and $17.33 \mathrm{~g} \mathrm{dm}^{-3}$, associated with soil water contents of 27.91 and $28.06 \%$, promoted greater diameter and mass of corms, respectively, at 147 days after plant emergence (Figures $5 \mathrm{~A}$ and $\mathrm{B})$.

It is observed that wood ash fertilization did not favor shoot and root dry matter production (Figure $3 \mathrm{~B}$ and $4 \mathrm{~B}$ ). However, the production of corms was favored by the use of this residue in the range of 14 to $17 \mathrm{~g} \mathrm{dm}^{-3}$, promoting corms with greater mass and larger diameters, in comparison to the treatments without wood ash fertilization.

This result is relevant, because the size of the plant and the flower spike is directly related to corm diameter. Cultivar and corm size also influence the fertilization requirement of gladiolus (Lehri et al., 2011). Therefore, the larger the corm, the greater will also be its nutritional reserve, promoting more vigorous growth, more intense flowering and greater postharvest durability.

Rosa et al. (2014), studying gladiolus as a function of $\mathrm{N}$ fertilization and corm diameter, observed that, in general, large corms promoted higher number and length of leaves, with low response to fertilization, while small corms were the most benefited by $\mathrm{N}$ fertilization, probably due to the lower reserve of nutrients.

Memon et al. (2009) verified that vegetative development and flower production were significantly influenced by corm size. There is a variation of increment in flower production, flower quality and in the production of corms and bulbils as a function of the size of the planted corm (Hossian et al., 2011). Therefore, it is evident the importance of wood ash as a source of nutrients for the production of corms for commercial purposes, because the larger and heavier the produced corms are, the greater will be the nutritional reserves, which will reflect in better production and quality of flowers.

Studies with wood ash fertilization on the production and nutrition of forage grasses in Cerrado Oxisol found that this solid residue increased production and chlorophyll content, and improved water use efficiency (Bonfim-Silva et al., 2013; Bezerra et al., 2014) and the nutritional quality of the grasses (Bonfim-Silva et al., 2014), showing the potential of wood ash as an alternative fertilizer in agriculture.

The application of wood ash was responsible for incorporating into the soil approximately $287 \mathrm{mg} \mathrm{dm}^{-3}$ of $\mathrm{K}_{2} \mathrm{O}\left(238 \mathrm{mg} \mathrm{dm}^{-3}\right.$ of $\mathrm{K}$ ), at the dose of $17 \mathrm{~g} \mathrm{dm}^{-3}$ (Table 2). According to the literature, $\mathrm{K}$ influences the translocation of sugars to the roots, bulbs and tubers, which are stored as reserve substances (Malavolta et al., 1997). Thus, the K supplied to gladiolus at the wood ash dose of $17 \mathrm{~g} \mathrm{dm}^{-3}$ was sufficient for these sugars to be translocated to the corms, which showed greater mass and diameter. However, it should be pointed out that the excess of any nutrient deranges the absorption of the others, which limits the vegetative potential. Bratti et al. (2012), studying the production of gladiolus as a function of liming and $\mathrm{K}$ fertilization, observed that the excess of $\mathrm{K}$ and $\mathrm{CaCO}_{3}$ not only compromised vegetative development and flower production, but also caused reduction in the diameter of the produced corms. These authors also observed that high $\mathrm{K}_{2} \mathrm{O}$ doses were responsible for the reduction in $\mathrm{Mg}$ absorption by plants. 
Corroborating the results of the present study, Pereira et al. (2009) evaluated the growth of gladiolus cultivated at different soil water tensions and observed that the best response was obtained when irrigations were applied in order not to allow soil water tension to exceed $15 \mathrm{kPa}$, close to field capacity.

The lowest value of volumetric soil water content $(7 \%)$ led to the production of corms classified as 7-8 with respect to perimeter, followed by the classes of 12-14 and 14-16 for water contents of 14 and $21 \%$, respectively, and from the water content of $28 \%$ on, the diameter was higher than $5.7 \mathrm{~cm}$, being classified as $>16 \mathrm{~cm}$ (Barbosa, 2011).

\section{Conclusions}

1. The best results for diameter and mass of corms of 'White Friendship' gladiolus occurred in the combinations of soil water content of $28 \%$ and wood ash doses of 14.31 and 17.33 $\mathrm{mg} \mathrm{dm}{ }^{-3}$, respectively.

2. The vegetative growth of the shoots of 'White Friendship' gladiolus is better at the soil water content of $26 \%$ and root growth decreases as soil moisture increases.

3. Wood ash fertilization is more relevant for the production of corms than for the vegetative growth of gladiolus.

\section{ACKNOWLEDGMENTS}

To the Coordination for the Improvement of Higher Education Personnel (CAPES), for the Master's scholarship to the first author and to the National Council for Scientific and Technological Development (CNPq), for the Research Productivity Grant to second and third authors.

\section{Literature Cited}

Barbosa, J. G. Palma de Santa Rita (gladíolo): Produção comercial de flores e bulbos. Viçosa: Imprensa Universitária, 2011. 113p.

Bezerra, M. D. L.; Bonfim-Silva, E. M.; Silva, T. J. A. Wood ash efect on the productive characteristics of Marandu grass in Cerrado soils. African Journal of Agricultural Research, v.9, p.2339-2344, 2014. http://dx.doi.org/10.5897/AJAR2014.8841

Bonfim-Silva, E. M.; Cabral, C. E. A.; Silva, T. J. A.; Moreira, J. C. F.; Carvalho, J. C. S. Cinza vegetal: Características produtivas e teor de clorofila do capim-marandu. Bioscience Journal, v.29, p.1215-1225, 2013.

Bonfim-Silva, E. M.; Santos, C. C. ; Silva, T J. A.; Scaramuzza, W. L. M. P. Concentration of nitrogen, phosphorus and potassium in tropical grasses fertilised with wood ash in cerrado oxisol. African Journal of Agricultural Research, v.9, p.549-555, 2014. http:// dx.doi.org/10.5897/AJAR2013.8278

Bratti, E. F.; Rosa, Y. B. C. J.; Silva, E. F.; Rosa Júnior, E. J.; Zárate, N. A. H.; Bíscaro, G. A.; Rosa, D. B. C. J. Cultivo de gladíolos em função das doses de calcário e potássio. Horticultura Brasileira, v.30, p.397-402, 2012. http://dx.doi.org/10.1590/S010205362012000300007

Costa, A. R. Texto academico: As relações hídricas das plantas vasculares. Lisboa: Universidade de Évora, 2001. 75p.
Darolt, M. R.; Bianco Neto, V.; Zambon, F. R. A. Cinza vegetal como fonte de nutrientes e corretivo de solo na cultura de alface. Horticultura Brasileira, v.11, p.38-40, 1993.

EMBRAPA - Empresa Brasileira de Pesquisa Agropecuária. Centro Nacional de Pesquisa em Solos. Manual de métodos de análise de solo. Rio de Janeiro: Embrapa CNPS, 1997. 212p.

EMBRAPA - Empresa Brasileira de Pesquisa Agropecuária. Sistema Brasileiro de Classificação de Solos 3.ed. revista ampliada. Brasília: EMBRAPA, 2013. 353p.

Farias, M. F.; Saad, J. C. C. Análise de crescimento do crisântemo de vaso, cultivar Puritan, irrigado em diferentes tensões de água em ambiente protegido. Acta Scientiarum. Agronomy, v.33, p.75-79, 2011. http://dx.doi.org/10.4025/actasciagron.v33i1.1763

Farias, M. F.; Saad, J. C. C; Carnietto, M.; Laschi, D. Efeito de tensões de água no solo na qualidade e longevidade floral do crisântemo de corte. Pesquisa Aplicada e Agrotecnologia, v.2, p.135-145, 2009. http://dx.doi.org/10.5777\%2Fpaet.v2i1.441

Hossian, M. J.; Amin, M. R.; Uddain, J. Effect of corm size and fifferent doses of phosphorus on the growth, corm and cormel development of gladiolus. Lybian Agriculture Research Center Journal International, v.2, p.9-14, 2011.

Kron, A. P.; Souza, G. M.; Ribeiro, R. V. Water deficiency at different developmental stages of glycine max can improve drought tolerance. Bragantia, v.67, p.43-49, 2009. http://dx.doi. org/10.1590/S0006-87052008000100005

Leão, R. A. O.; Teixeira, A. S.; Canafístula, F. J. F.; Mesquita, P. E. G.; Coelho, S. de L. C. Desenvolvimento de um dispositivo eletrônico para calibração de sensores de umidade do solo. Revista Brasileira de Engenharia Agrícola, v.27, p.294-303, 2007. http://dx.doi. org/10.1590/S0100-69162007000100024

Lehri, S. M.; Kurd, A. A.; Rind, M. A.; Bangulza, N. A. The response of Gladiolus tristis L. to N and P2O5 fertilizers. Sarhad Journal of Agriculture, v.27, p.185-188, 2011.

Malavolta, E.; Vitti, G. C.; Oliveira, S. A. Avaliação do estado nutricional das plantas: princípios e aplicações. 2.ed. Piracicaba: Potafós, 1997. 319p.

Melo, A. S. de; Suassuna, J. F.; Fernandes, P. D; Brito, M. E. B; Suassuna, A. F; Aguiar Netto, A. O. Crescimento vegetativo, resistência estomática, eficiência fotossintética e rendimento do fruto da melancieira em diferentes níveis de água. Acta Scientiarum Agronomy, v.32, p.73-79, 2010. http://dx.doi.org/10.4025/ actasciagron.v32i1.2136

Memon, Noor-Un-Nisa; Qasim, M.; Jaskani, M. J.; Ahmad, R.; Anwar, R. Effect of various corm sizes on the vegetative, floral and corm yield attributes of gladiolus. Pakistan Journal of Agricultural Sciences, v.46, p. 13-19, 2009.

Pereira, J. R. D.; Carvalho, J. A.; Paiva, P. D. O.; Silva, D. J.; Souza, A. M. G.; Souza, K. J. Crescimento e produção de hastes florais de gladíolo cultivado sob diferentes tensões de água no solo. Ciência e Agrotecnologia, v.33, p.965-970, 2009. http://dx.doi.org/10.1590/ S1413-70542009000400004

Rena, A. B.; Guimarães, P. T. G. Sistema Radicular do Cafeeiro: Estrutura, distribuição, atividade e fatores que o influenciam. Belo Horizonte: Empresa de Pesquisa Agropecuária de Minas Gerais. 2000. 80p.

Rosa, Y. B. C. J.; Wollemberg, S.; Silva, E. F.; Rosa Junior, E. J.; Nunes, M. F.; Sorgato, J. C.; Jardim Rosa, D. B. C.; Soares, J. S.; Rosa, C. S. L. Desenvolvimento de gladíolos em função da adubação nitrogenada e diâmetro do cormo. Revista Brasileira de Horticultura Ornamental, v.20, p.87-92, 2014. 
SAS Institute. SAS: User's guide: Statistics. 9.ed. Cary, 2002. $943 \mathrm{p}$.

Silva, C. R.; Andrade Júnior, A. S.; Alves Júnior, J.; Souza, A. B. de; Melo, F. B.; Coelho Filho, M. A. Calibration of a capacitance probe in a Paleudult. Scientia Agrícola, v.64, p.636-640, 2007. http:// dx.doi.org/10.1590/S0103-90162007000600012

Silva, F. R.; Albuquerque, J. A.; Gatiboni, L. C.; Costa, A. Uso da cinza da combustão de biomassa florestal como corretivo de acidez e fertilidade de um Cambissolo Húmico. Revista de Ciências Agroveterinárias, v.12, p.304-313, 2013.
Sousa, A. E. C.; Bezerra, F. M. L.; Sousa; C. H. C.; Santos, F. S. S. Produtividade do meloeiro sob lâmina de irrigação e adubação potássica. Engenharia Agrícola, v.30, p.271-278, 2010. http:// dx.doi.org/10.1590/S0100-69162010000200009

Souza, C. F.; Matsura, E. E. Avaliação de sondas de TDR multihaste segmentadas para estimativa da umidade do solo. Revista Brasileira de Engenharia Agrícola e Ambiental, v6, p.63-68, 2002. http://dx.doi.org/10.1590/S1415-43662002000100012

Taiz, L.; Zeiger, E. Fisiologia vegetal. 3.ed. Porto Alegre: Artmed, 2010. 719p. 